WSRC-MS--92-017

DE92 011056

\title{
HYDROGEN GENERATION DURING TREATMENT OF SIMULATED HIGH-LEVEL RADIOACTIVE WASTE WITH FORMIC ACID (U)
}

by

\author{
J. A. Ritter, J. R. Zamecnik, and C. W. Hsu \\ Westinghouse Savannah River Company \\ Savannah River Site \\ Aiken, South Carolina 29808
}

A paper proposed for presentation at the

International High Level Radioactive Waste Management Conference

Las Vegas, Nevada

April 12 - 16, 1992

\section{DISCLAIMER}

and for publication in the proceedings

\begin{abstract}
This report was prepared as an account of work sponsored by an agency of the United States Government. Neither the United States Government nor any agency thereof, nor any of their employees, makes any warranty, express or implied, or assumes any legal liability or responsibility for the accuracy, completeness, or usefulness of any information, apparatus, product, or process disclosed, or represents that its use would not infringe privately owned rights. Reference herein to any specific commercial product, process, or service by trade name, trademark, manufacturer, or otherwise does not necessarily constitute or imply its endorsement, recommendation, or favoring by the United States Government or any agency thereof. The views and opinions of authors expressed herein do not necessarily state or reflect those of the United States Government or any agency thereof.
\end{abstract}

This paper was prepared in connection with work done under Contract No. DE-AC09-89SR18035 with the U.S. Department of Energy. By acceptance of this report, the publisher and/or recipient acknowledges the U.S. Government's right to retain a nonexclusive, royalty-free license in and to any copyright covering this report, along with the right to reproduce and to authorize others to reproduce all or part of the copyrighted report. 


\title{
IYDROGEN GENERATION DURTNG TREATMENT OF SIMUIATIED HIGII-LEVEL RADIOACTIVE WASTIE WITII FORMIC ACID (U)
}

\author{
J. A. Ritter, J. R. Zumecnik and C. W. IIsu
}

\author{
Westinghouse Savannah River Company \\ Savannah River Laboratory \\ Aiken, SC 29808 \\ (803) 725.6295
}

\begin{abstract}
ABSTRAC'T
and

The Integrated Defense Waste Processing Facility (DWPF) Melter System (II)MS), operated by the Savanuah River Laboratory, is a one-fifth scale pilot facility used in support of the start-up and operation of the Department of Encrgy's DWPF. Five IDMS runs determined the effect of the presence of noble metals in IILW sludge on the $\mathrm{H}_{2}$ generation rate during the preparation of melter feed with formic acid. Overall, the results clearly showed that $\mathrm{H}_{2}$ zeneration in the DWPF SRAT could, at times, exceed the lower flammable limit of $\mathrm{H}_{2}$ in air (4 vol\%), depending on such factors as offgas generation and air inleakage of the DWPF vessels. Therefore, the installation of a forced air purge system and $\mathrm{H}_{2}$ monitors were recommended to the DWPF to control the generation of $\mathrm{H}_{2}$ during melter feed preparation by fuel dilution.
\end{abstract}

\section{INTRODUCTION}

The Defense Waste Processing Facility (DWPF), located at the Savannah River Site (SRS), will be the United States' first facility 10 immobilize high-level radioactive waste (HLW) in a borosilicate glass matrix for storage in an offsite geologic repository. The Savannah River Laboratory (SRL) operates two enginecring-scale demonstration facilities to support the DWPF: the Precipitate Hydrolysis Experimental Facility (PliEF) ${ }^{2}$ and the Integrated DWPF Melter System (JDMS) $.3,4$ This paper is concerned with the one. fifth scale IDMS feed preparation system, as related to the gencration of $\mathrm{H}_{2}$.

The generation of $\mathrm{H}_{2}$ during the treatment of HLW with formic acid was considered extremely important because of the possibility of forming a flammable atmosphere in the vapor spaces above the feed preparation reactor and associated tanks and offgas lines of an air laden system. In 1988, Wiemers 5 at the Pacific Northwest Laboratory was the first to report the generation of significant amounts of $\mathrm{H}_{2}$ during the treatment of
Hanford simulated HLW with formic acid. The $\mathrm{H}_{2}$ was purportedly caused by the noble metal. catalyzed decomposition of the formic acid. Formic acid is used to treat HLW to improve its chemical and theological properties, and noble metals occur naturally in HIW as fission products. In $1990, \mathrm{Hsu}^{6}$ at the SRL confirmed that SRS noble metal containing simulated HLW would also produce $\mathrm{H}_{2}$. Therefore, five IDMS runs were performed to characterize the generation of $\mathrm{H}_{2}$ during the preparation of melter feed with formic acid and to obtain design information for the DWPF.

The primary and long-term objective of IDMS noble metals runs was to determine the effect of noble metals deposition in the melter. However, based on the work by $\mathrm{Hsu}^{6}$ a secondary, but equally important, objective was to characterize the generation of $\mathrm{H}_{2}$ during melter feed preparation. Three types of SRS simulated HLW sludges were tested: Blend (BL), Heavy Metal (HM) and Purex (PX). Table 1 compares the sludges, along with the precipitate hydrolysis aqueous (PHA) product obtained from the PHEF. Table 2 lists the concentrations and chemical forms of the noble and other metals added to the sludges prior to each run. Note that only BL contained IIg. Since mercury is known to form amalgams with noble metals, it was not added to the other sludges in an attempt to produce the highest possible $\mathrm{H}_{2}$ generation rate.

\section{METAL-CATALYZED DECOMPOSITION OF AQUEOUS FORMIC ACID}

Metal-catalyzed decomposition of gaseous or aqueous formic acid produces $\mathrm{H}_{2}$ according to the following reaction:

$$
\mathrm{HCOOH} \stackrel{\text { catalyst }}{-} \mathrm{CO}_{2}+\mathrm{H}_{2}
$$

This reaction is postulated 10 proceed via a helerogeneous mechanism involving a surface formate ion intermediate? The metal catalyzed 
decomposition of gascous formic acid to priduce $\mathrm{H}_{2}$ has becn sludied extensively as evidenced by the inclusion of this topic in most text books dealing with heterogeneous catalysis (e.g., see Salterficld) ${ }^{8}$. However, tho same is not truc for the decomposition of aqueous formie acid, where much less work has been done.?,10,11

Table 1. Characterization of Three SRS Sludges and PHAa

Species or

\begin{tabular}{|c|c|c|c|c|}
\hline Measurement & BL & $p X$ & $\mathrm{HM}$ & 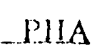 \\
\hline Al & 6.86 & 6.33 & 8.68 & 0.04 \\
\hline B & $\ldots$ & $\cdots$ & . $\ldots$ & 3.15 \\
\hline $\mathrm{Ba}$ & 0.30 & 0.52 & 0.19 & \\
\hline $\mathrm{Ca}$ & 1.55 & 3.30 & 1.11 & 0.09 \\
\hline $\mathrm{Cr}$ & 0.05 & 0.01 & 0.06 & - \\
\hline Cs & $\ldots$ & $2 x-$ & $\cdots$ & 0.55 \\
\hline $\mathrm{Cu}$ & 0.16 & 0.19 & $=0.06$ & 0.47 \\
\hline $\mathrm{Fe}$ & 20.92 & 22.32 & 4.31 & 0.34 \\
\hline $\mathrm{K}$ & 0.34 & $\ldots$ & 0.18 & 8.56 \\
\hline $\mathrm{Mg}$ & 0.14 & 0.11 & 0.12 & 0.03 \\
\hline$M n$ & 4.79 & 8.00 & 4.72 & 0.16 \\
\hline $\mathrm{Na}$ & 4.28 & 3.55 & 7.76 & 8.35 \\
\hline Nd & 0.18 & 0.35 & 1.37 & 0.01 \\
\hline $\mathrm{Ni}$ & 1.87 & 4.28 & 0.96 & 0.05 \\
\hline$P$ & 0.07 & 0.13 & 0.06 & $\cdots$ \\
\hline $\mathrm{Pb}$ & 0.44 & 0.99 & 0.26 & $\cdots$ \\
\hline $\mathrm{Si}$ & 3.90 & 2.65 & 3.71 & 0.05 \\
\hline $\mathrm{Zn}$ & 0.33 & 0.49 & 0.13 & 0.01 \\
\hline $\mathrm{Zr}$ & 0.14 & $\cdots$ & $\cdots$ & $\cdots$ \\
\hline $\mathrm{COOH}^{-1}$ & $\cdots$ & $\cdots$ & $\ldots$ & 25.36 \\
\hline $\mathrm{SO}_{4}^{-2}$ & 0.50 & 0.97 & 0.44 & 0.28 \\
\hline $\mathrm{NO}_{3}^{-1}$ & 0.88 & 0.42 & 1.42 & 24.03 \\
\hline $\mathrm{NO}_{2}^{-1}$ & 8.62 & 2.14 & 9.31 & $\cdots$ \\
\hline $\mathrm{Cl}-1$ & 0.70 & 0.01 & $\cdots$ & 0.16 \\
\hline$F^{-1}$ & 0.54 & $\cdots$ & $\cdots$ & 0.01 \\
\hline Density $(\mathrm{g} / \mathrm{ml})$ & 1.09 & 1.09 & 1.09 & 1.02 \\
\hline Total Solids & 11.31 & 11.10 & $\begin{array}{l}10.96 \\
149\end{array}$ & 3.80 \\
\hline Total Acid (M) & $\ldots$ & $\ldots$ & ... & 0.13 \\
\hline $10 C$ & 0.10 & 0.10 & 0.08 & 10.54 \\
\hline TIC & 0.26 & 0.78 & 0.25 & 0.12 \\
\hline
\end{tabular}

a wi\% dry unless noted; $b$ wi\% wet

Müller and Loerpabel investigated the platilium melals (Pd, $\mathrm{Ir}, \mathrm{Rh}, \mathrm{Pt}, \mathrm{Os}$ and $\mathrm{Ru}$ ) in aqueous solutions of formic acid and showed that at $100{ }^{\circ} \mathrm{C}$ only $\mathrm{CO}_{2}$ and $\mathrm{H}_{2}$ were produced by all of these metals, and their catalytic activily approximately decreased in the order listed. They also demonstrated that an induction period existed for some of the metals (Os and Ru), which was the time for formic acid 10 reduce the metal to a catalytically active form. The induction lime was strongly dependent on the metal, emperature and presence of anions, and generally a shorter or no induction period resulted in a higher maximum gas generation ate. Purlhermore after a forximum gas gencration rate was cxhibited, the catalytic activity decreased and, in gencral, more rapidly with higher maximum gas gencration rates. This decrease in catalytic activity was altributed to the time dependent agglomeration of the fine metal catalyst particles thereby decreasing their active surface area.

Table 2. Noble and Other Metals in the Simulated HLW*

\begin{tabular}{|c|c|c|c|c|}
\hline \multirow[b]{2}{*}{ Element } & \multirow[b]{2}{*}{ Species } & \multicolumn{3}{|c|}{ IDMS Sludge } \\
\hline & & $B L$ & $\mathrm{HM}$ & HX \\
\hline$R u$ & $\mathrm{RuNO}(\mathrm{OH})_{3}$ & 0.100 & 0.217 & 0.239 \\
\hline $\mathrm{Rh}$ & $\mathrm{Rh}\left(\mathrm{NO}_{3}\right)_{2}$ & 0.018 & 0.041 & 0.038 \\
\hline $\mathrm{Pd}$ & $\mathrm{Pd}\left(\mathrm{NO}_{3}\right)_{2}$ & 0.045 & 0.085 & 0.079 \\
\hline $\mathrm{Ag}$ & $\mathrm{AgNO}_{3}$ & 0.014 & 0.015 & 0.014 \\
\hline $\mathrm{Se}$ & $\mathrm{SeO}_{2}$ & 0.002 & 0.004 & 0.004 \\
\hline Te & $\mathrm{TcO}_{2}$ & 0.022 & 0.051 & 0.048 \\
\hline $\mathrm{Hg}$ & $\mathrm{Ig}\left(\mathrm{NO}_{3}\right)_{2}$ & 1.588 & 0.000 & 0.000 \\
\hline
\end{tabular}

* wi\% elemental dry basis

Ruthven and Upadhyel0 studied the Pd catalyzed decomposition of aqueous formic acid in 0.05 to $0.9 \mathrm{M}$ solutions and also showed that no other gaseous products were detected other than $\mathrm{CO}_{2}$ and $\mathrm{H}_{2}$. Moreover, the heat of adsorption was comparable to that found in vapor phase studies which possibly indicated a similarity in vapor and liquid phase mechanisms. Also, their Pd catalyst continuously deactivated during the course of reaction, but they attributed it to the adsorption of the $\mathrm{H}_{2}$ product. A square root dependence of the rate of $\mathrm{H}_{2}$ production on the formic acid concentration was also observed.

Hill and Winterbottom 11 investigated the Pd catalyzed decomposition of aquerus formic acid in various sodium formate solutions. They reported activation energies ranging from 21 to $42 \mathrm{~kJ} / \mathrm{mol}$, where the higher values occurred at the extremes of the composition range. Moreover, they observed a reaction rate dependence ranging from 0.33 to 1.07 depending on whether formic acid or formate was predominantly present in solution. This range was in gond agreement with that reported by Ruthen and liablige, lo

\section{MELTER FEED PREPARATION}

The IDMS feed preparation system consists of a reactor (SRA'T) and an offass sy'stem, which has two condensers in series. Since $\mathrm{H}_{2}$ is gencrated in the SRAT, a potential exists for the lower flammable limit (LFL) of $\mathrm{H}_{2}$ in air (4 vol\%) to be exceeded in the offgas lines after the condensers. A detailed description of the IDMS feed preparation equipment, along with the processing cycle, has been given elsewherc. 1,3,4 
However, in order 10 understand the discussion on the generation of $11_{2}$, a brief summary of the processing eycle is given below.

Typically, for each run made in the IDMS, approximately 4,000 of simulated alkaline sludge were transferred to the reactor (SRAT). Mercury was added to the SRAT :(BL runs only) as mercuric nitrate, selenium and tellurium as dissolved dioxides, ruthenium as nitrosyl ruthenium hydroxide and the three remaining noble metals $(\mathrm{Ag}, \mathrm{Pd}$ and $\mathrm{Rh}$ ) as soluble nitrate salis (sce Table 2). The temperature of the SRA'T was increased 10 between 93 and $96^{\circ} \mathrm{C}$ to add formic acid. Depending on the type of sludge (sce Table 3 , below), 114 to $227 \mathrm{~L}$ of 90 wi\% formic acid were added at $0.4 \mathrm{~L} / \mathrm{min}$ per $1,000 \mathrm{~L}$ of sludge. After formic acid addition, the SRAT was boiled and refluxed for 6 to $8 \mathrm{hr}$ to allow the slower reactions 10 proceed and steam strip mercury (when present) from the sludge. Next, approxtitiately $7,200 \mathrm{~L}$ of Plis (from the PHLF) were added at $7.61 . / \mathrm{min}$ and, at the same lime, condensate was removed from the system This step required an additional $13 \mathrm{hr}$ during which time more mercury stripping occurred. When all the PHA was added, a slurry consisting of water, borosilicate glass frit and $4 \mathrm{~L}$ of formic acid was added to the SRAT at $80 \mathrm{~L} / \mathrm{min}$ while still in the concentration mode. After this addition, $10 \mathrm{hr}$ were required 10 concentrate the sludge to a specified solids concentration for feeding to the melter.

\section{RESULTS AND DISCUSSION}

BLl was the first noble metals run in the IDMS, but only very low levels of $\mathrm{H}_{2}$ were detected during the time when $\mathrm{H}_{2}$ was monitored. BL2 was the second noble metals run and the first time a significant amount $\mathrm{H}_{2}$ was detected in the offgas during feed preparation. This result redirected the objectives of future noble metals runs in the IDMS. The next four IDMS runs (HM2, HM3, PXI and $\mathrm{PX}$ 2) were designed to 1) characterize $\mathrm{H}_{2}$ generation from HM (HM2) and PX (PX1), as these sludges have the highest noble metals concentrations of all the different sludges, 2) determine the effect of a vessel heel on the $\mathrm{H}_{2}$ generation rate (HM3 contained a heel from HM2), 3) determine the effect of nitrite on the $\mathrm{H}_{2}$ generation rate by comparing PXI with IIM2 (the level of corrosion inhihitor, nitrile, added to aclual HLW could vary by afactor of five), and 4) determine the effect of exuess formic arid on the $\mathrm{H}_{2}$ generation rate by adding $25 \%$ more formic acid to PX2 than PX1.

Each of these IDMS runs is discussed in detail below within the realm of a parametric study, The variables which had the greatest impact on the $\mathrm{H}_{2}$ generation rate were determined from a laboratory study. 12 Also, all of the sludges were essentially equivalent, except for the presence of a few species, e.g., noble metals, nitrite and mercury. Table 3 shows that, except for 131.2 and PX2. (explanations are given helow), even the amount of formic acid requiredl 3 for each run did not vary widely.

Table 3. Formic Acid (FA), Sludge Volume and Solids Content

\begin{tabular}{lccc} 
Run & EA $(L)$ & Sludge(L) & wtze Solids \\
\hline BL1 & 121 & 4,428 & 19.0 \\
BL2 & $227^{a}$ & 4,164 & 30.0 \\
HM2 & 117 & 4,164 & 14.9 \\
HM3 & 98 & 5,360 & 18.5 \\
PX1 & 136 & 3,883 & 14.5 \\
PX2 & $170^{b}$ & 4,315 & 14.2
\end{tabular}

a $91 \mathrm{~L}$, due to caustic heel; b 34 L to lest effect of excess FA ( $\sec t e x t)$

It should be noted that all of the runs exhibited very low levels of $\mathrm{H}_{2}$ early in formic acid addition and reflux. These levels were of little concern, however, as they were far below the LFl. The $\mathrm{H}_{2}$ generation rates of interest were those which increased rapidly to levels that could have easily exceeded the LFL.

\section{BL Runs: First Noble Metals Operations}

For BL1, a $\mathrm{H}_{2}$ monitor was available only from the beginning of the run to a few hours into PliA addition. During that time, the $\mathrm{H}_{2}$ generation rate never exceeded $0.008 \mathrm{~mol} / \mathrm{min}$. Therefore, it was concluded that the generation of $\mathrm{H}_{2}$ was not critical during HLW processing. However, it is seen from Figure 1 that $\mathrm{NO}_{\mathbf{x}}$ was produced (from nitrite $)^{4}$ throughout formic acid addition and even during reflux. Note that the oscillations in the profiles were due 10 slight fluctuations in temperature, as the SRAT was apparently not at boiling. The broad $N O_{x}$ profile indicated that there was a significant amount of unreacted nitrite remaining in the sludge, which was later verified by liquid analyses. The impact of this residual nitrite on the $\mathrm{H}_{2}$ generation rate was not known at that time and understood only after several months of research.

For BL.2, approximately twice the formic acid was added at wice the foed rate of BL. The additional formic acid was required to neutralize a caustic heel from an $10 M S$ waste water process rnalfunction). Figure 2 shows that, in contrast to the BL, results, the $\mathrm{NO}_{x}$ profile was quite narrow and decreased below the detection limit after about $7 \mathrm{hr}$. Both of these results were probably caused by a combination of the faster feed rate and greater amount of formic acid added in BI.2. The interesting result was that a significant amount of $\mathrm{H}_{2}$ was not generated until the $\mathrm{NO}_{x}$ concentration decreased to below the detection limit, at which lime the $\mathrm{H}_{2}$ gencration rate rapidly increased, but peaked three times. The 
first two peaks were again calused by fluctuations in temperature, but this time they were due to process shuidowns for safety concerns, as this was the first time that the $\mathrm{H}_{2}$ gencration ratc was on the order of the LFL. After the first peak, the system inerted with a $\mathrm{N}_{2}$ purge instead of air. When reflux operations continued, the $\mathrm{H}_{2}$ generation rate rapidly increased again, peaked and slowly decreased until reflux was finished at approximately $18 \mathrm{hr}$.

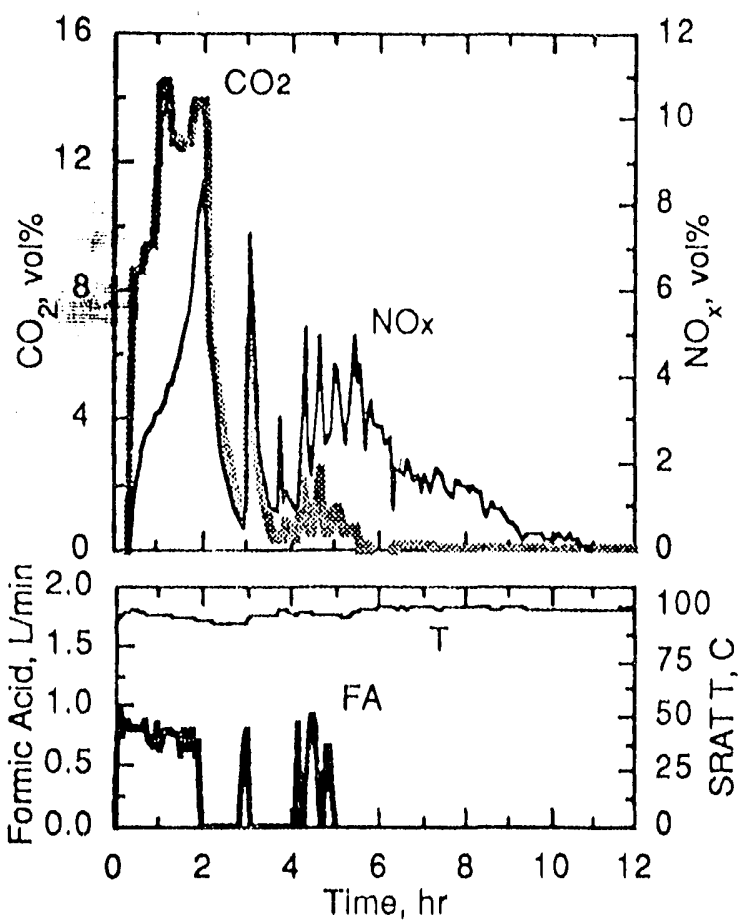

Figure 1. Offgas composition profiles for $\mathrm{BL}$ during formic acid addition and reflux.

It is clear from these results for BL2 that, during the latter part of PHA addition of BL1, a significant amount of $\mathrm{H}_{2}$ was probably generated; and, the delay or induction period was most likely caused by the unreacted nitrite in the sludge. Low levels of $\mathrm{NO}_{x}$ were indeed observed well into PHA addition. However, it must be emphasized that, during BL1, a potential safety hazard did not exist since, during PliA addition, a $\mathrm{N}_{2}$ purge has always been used to inert the SRAT.

During PlHA addition of BL.2 (not shown), the $\mathrm{H}_{2}$ generation rate continuously decreased and eventually leveled off at about $0.1 \mathrm{~mol} / \mathrm{min}$. The profile corresponded approximately to a first order decrease in the $\mathrm{II}_{2}$ generation ate. The deactivation may be explained by agglomeration of the catalyst particles, 9 or by irreversible adsorption of 112.10 In either case, the catalyst structure was apparently allered and rendered somewhat inactive. Note that, Hlthough mercury is well known to form amalgams with noble metals and thus deactivate their calalytic activity, in this caso, the effect of mercury is not clearly understood.
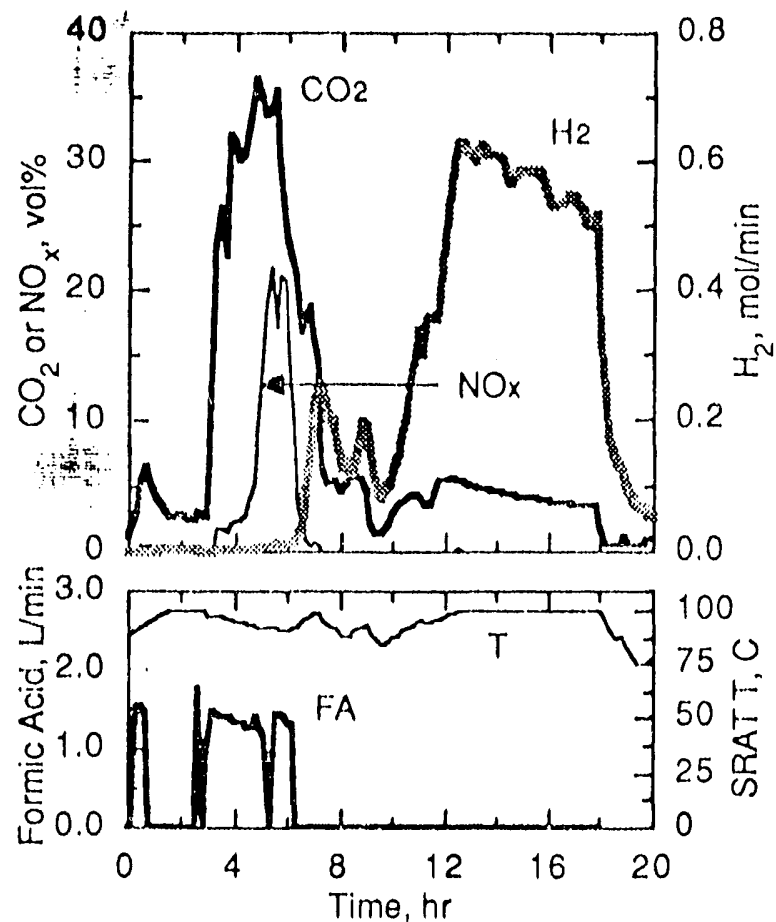

Figure 2, Offgas composition profiles for BL2 during formic acid addition and reflux.

The maximum $\mathrm{H}_{2}$ generation rate observed during BL2 corresponded to levels that exceeded the LFL in the IDMS SRAT. Thus, since there is presently no forced air purge system on the DWPF SRAT, based on its design air inleakage, the possibility of exceeding the LFL during feed preparation also existed. This result redirected the IDMS program to address this polential DWPF safety hazaid. The results of this redirection form the basis of the remainder of this paper.

\section{HM Runs: Effect of SRAT Heel}

The DWP? SRAT Hill be oprerated with a 30 vol\% heel, which contains noble melals as well as formate. These sprecies may boh adversely affect the $\mathrm{H}_{2}$ generation rate; therefore, two IDMS runs were performed will HM sludge 10 ascertain the effect of a well characterized vessel heel. Also, actual $11 \mathrm{M}$ is one of the sludges which contain the highest noble metals concentrations; thus, its was imperative that it be characterized with respect 10 $\mathrm{H}_{2}$ Ecneration.

HM2 was performed without a heel, whereas $11 \mathrm{M} 3$ contained a 22 vol\% heel from $11 \mathrm{M} 2$. 
Table 3 shows that the volume of new sludge and consequently the amount of formic acid added to each run were similar. It was not surprising then, that the $\mathrm{CO}_{2}$ and $\mathrm{NO}_{x}$ profiles displayed in Pigure 3 for llM2 were similar to those for $1 \mathrm{MM} 3$ (not shown). This result indicated that the heel had no effect on the non-catalytic reactions. The effect on the catalytic reaction which produced $\mathrm{H}_{2}$ (Equ. 1) was not as clear, however.

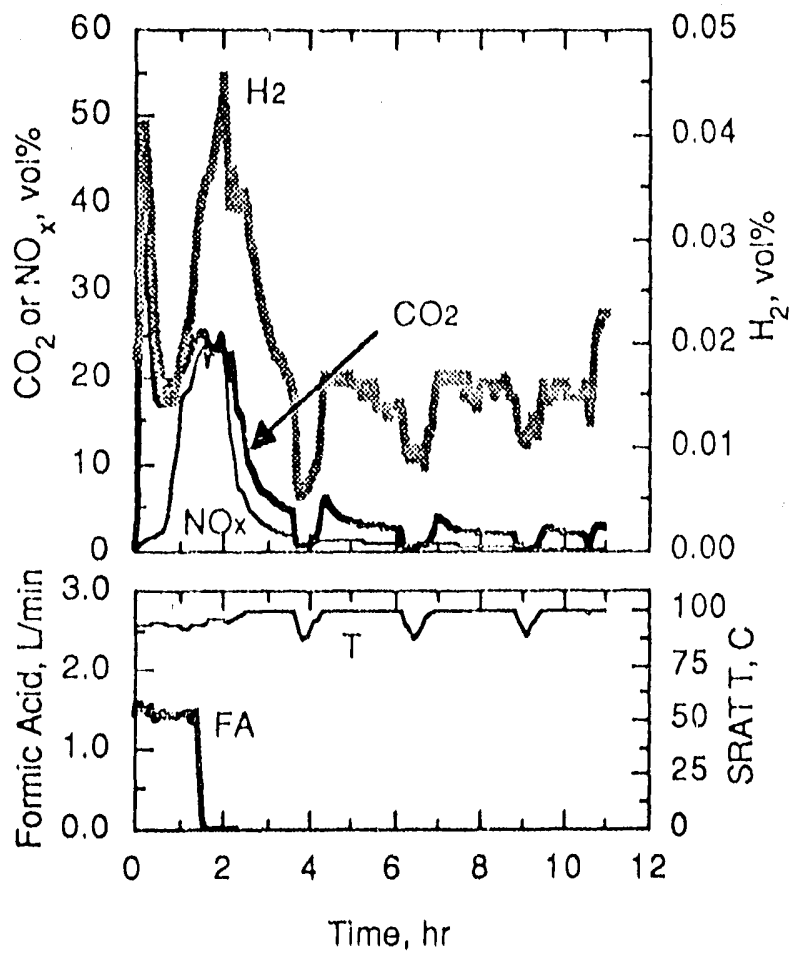

Figure 3. Offgas composition profiles for HM2 during formic acid addition and reflux.

It is seen from Figure 4 that, when the heel was present, there was a $7 \mathrm{hr}$ delay before the rapid increase in the $\mathrm{H}_{2}$ generation rate occurred. However, part of the delay exhibited in HM3 may have been caused by the large decrease in the SRAT temperature (due to safety interlocks), which occurred just prior to the rapid increase in H2. A similar temperature decrease was seen in 11M2, which may have also delayed the increase in $\mathrm{H}_{2}$.

Figure 4 also shows that there was a significant decrease in the maximum $\mathrm{H}_{2}$ generation rate when the heel was present. However, this effect was more lhan likely caused by the $3 \mathrm{hr}$ time span (at about $30 \mathrm{hr}$ ) during which the SRAT temperature was well below boiling. Moreover, constant boiling conditions were not attained until approximately $37 \mathrm{hr}$, which was when IIM3 exhibited its maximum $\mathrm{H}_{2}$ generation rate of $0.038 \mathrm{~mol} / \mathrm{min}$. Conversely,
$11 \mathrm{M} 2$, which reached boiling much faster, exhibited a maximum $\mathrm{H}_{2}$ getletation rate of 0.159 mol/min.

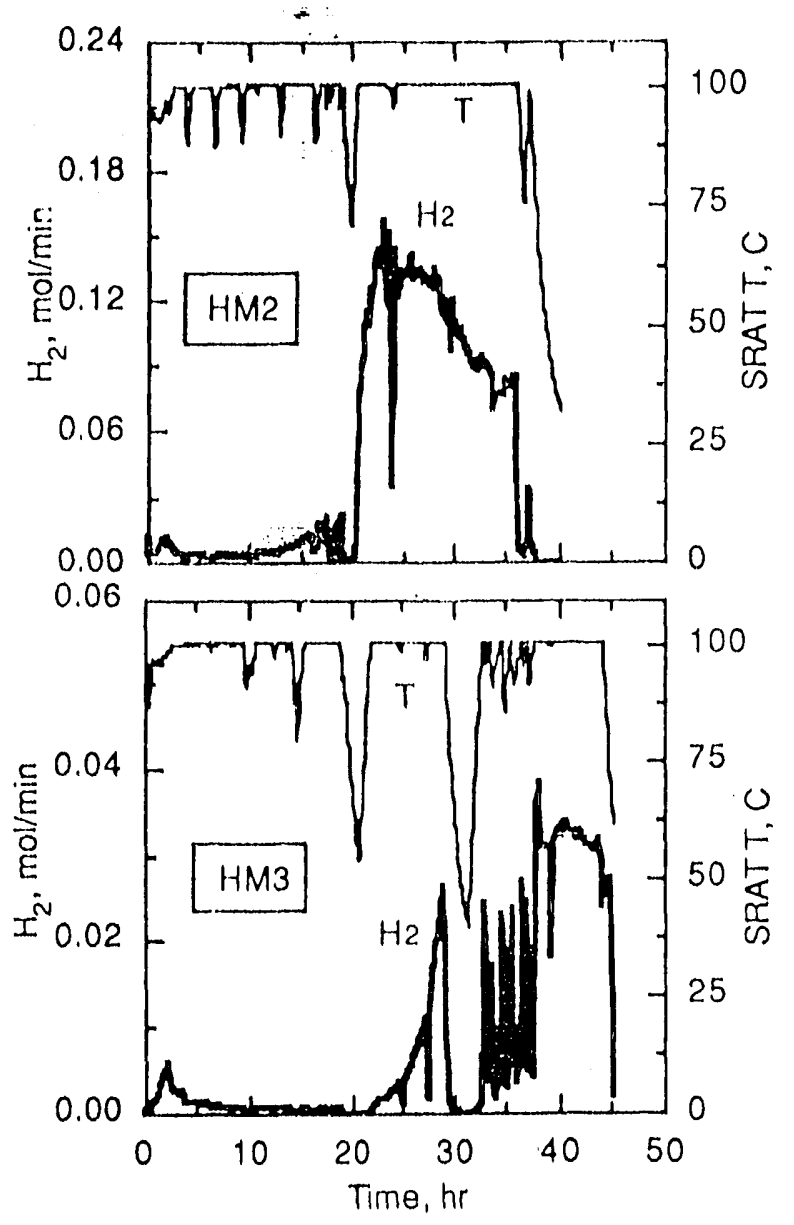

Figure 4. $\mathrm{H}_{2}$ generation rates for $11 \mathrm{M} 2$ and HM3 through PHA addition.

Clearly, based on the data presented in Figure 4 , it is not apparent what the maximum $\mathrm{H}_{2}$ generation rate would have been for $1 \mathrm{HM} 3$ if no interruptions occurred. However, it did appear that the maximum $\mathrm{H}_{2}$ generation rate for $11 \mathrm{M} 3$ would not have exceeded that exhibited by IIM2. This result suggested that the excess formate and the residual noble metals in the heel had litlle effect on the production of $\mathrm{H}_{2}$, which was also perified in the laboratory.12 Also, since the additional volume of sludge, due to the hecl, diluted the incoming formic acid, the effect of formic acid would have been less (see below)

\section{HM and PX Runs: Effect of Nitrite}

Table 1 show's that the only significant difference between $H M$ and $P X$ was the concentration of nitrite: PX was prepared with 
one-fifth of that added to HIM. Morcover, it is seen from trable 2 that the same amounts of noble metals were also added to each sludge. Table 3 shows that similar amounts of formic acid were required by $H M 2$ and $P X 1$, where the difference was essentially due to the difference in the nitrite.

It is seen from Figures 3 and 5 that the NOx concentrations for HM2 and PX1 peaked at about 25 and 0.6 vol\%, respectively. This result was a direct consequence of the initial level of nitrite in each sludge. For $\mathrm{PX} 1$, a significant amount of $\mathrm{H}_{2}$ was generated at about $10 \mathrm{hr}$ into the cycle, whereas for HM2, it took over $17 \mathrm{hr}$, An even shorter induction period probably would have resulted if the formic acid feed rate of PXI was not reduced part way through the cycle (for process operation reasons), resulting in a slower nitrite destruction rate.

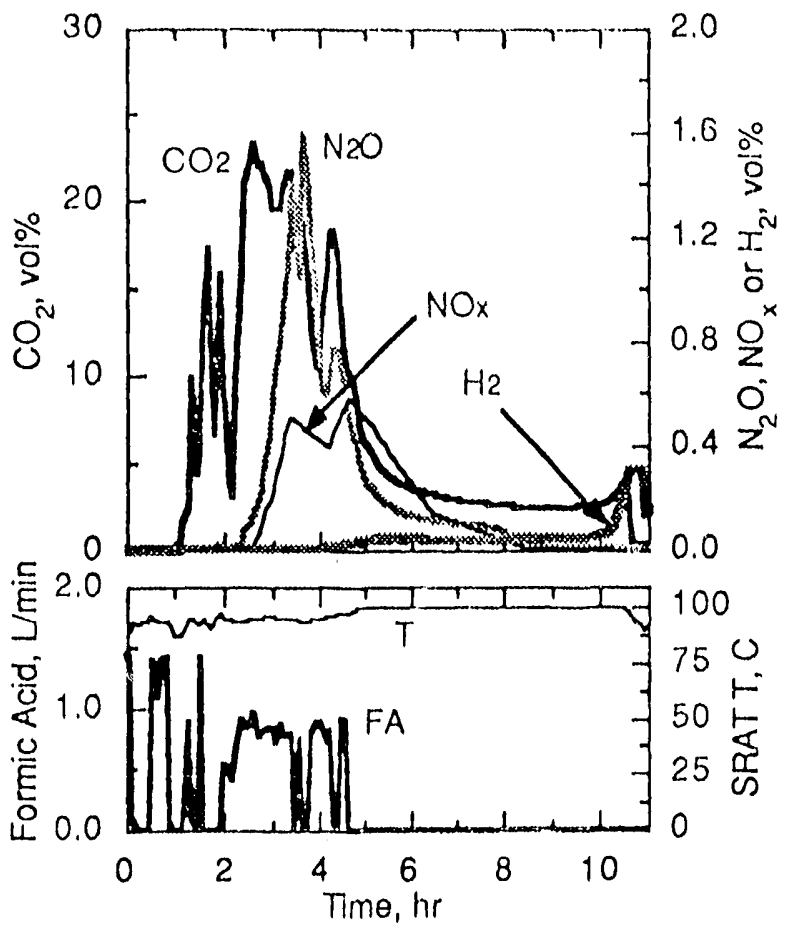

Figure 5. Offgas composition profiles for PXI during formic acid addition and reflux.

These results showed that the induction period was reduced by $41 \%$ and the peak $\mathrm{H}_{2}$ generation rate increased by a factor of four. The nitrite apparently impeded the formation of the active form of the noble metals. A similar effect of the presence of anions in solution has also been reported, but with no explanation. ${ }^{9}$

Based on these results, the same delay should have occurred in BL2. llowever, it was possible that formic acid in excess of that required 13 may have been used, The excess formic acid accelerated the destruction of nitrite (compare the $\mathrm{NO}_{x}$ levels of BL.1 and BL2) and thus shortened the induction period for $\mathrm{H}_{2}$ generation. The rapid destruction of the nitrite, in conjunction with the proven effect of excess formic acid (see below), may have contributed to the unusually high maximum $\mathrm{H}_{2}$ generation rate exhibited in BL2.

BL2 was unusual in that it contained about half of the noble metals as PX (see Trable 2), yet the peak $\mathrm{H}_{2}$ generation rate was similar to PX1. Laboratory results showed that the peak $\mathrm{H}_{2}$ generation rate was essentially proportional to the amount of noble melals and that excess formate had little effect on the $\mathrm{H}_{2}$ generation rate. 12 These laboratory results further verified the supposition that excess formic acid may have been inadvertently added to BL2, However, the role that mercury may have played in $13 L 2$ was also not clear.

\section{PX Runs: Effect of Excess Formic Acid}

Laboratory experiments demonstrated that the amount of formic acid added to the sludge had a marked affect on the $\mathrm{H}_{2}$ generation rate. ${ }^{12}$ As a result, two IDMS runs were performed to test this hypothesis on a large scale. A nominal amount of formic acid was added to PX1 and $25 \%$ excess 10 PX2 (sce Table 3). Note that PX was also prepared with one-fifth the nitrite that was added to the other sludges (see Table 1). Therefore, based on results just discussed on the effect of nitrite, the laboratory work and the fact that PX has one of the highest noble metal contents (see Table 2), it was anticipated that the PX runs would exhibit the highest $\mathrm{H}_{2}$ generation rates of all the IDMS runs.

Figure 5 shows that very little $\mathrm{H}_{2}$ was produced up to the end of reflux. Nevertheless, it is seen from Figure 6 that, at about $10 \mathrm{hr}$, the $\mathrm{H}_{2}$ generation rate increased rapidly and caused numerous process interlocks, as is apparent from the erratic temperature profile. Nevertheless, a distinct peak-like shape spanning from 10 to $20 \mathrm{hr}$ was exhibited. The maximum $\mathrm{H}_{2}$ generation rate ranged from 0.4 to $0.61 \mathrm{~mol} / \mathrm{min}$. The higher value may have been due to a surge of offgas from the SRAT, which always results just before the SRAT leaches boiling conditions. The characteristic deactivation (i.e., the first order decrease in the $\mathrm{H}_{2}$ generation rate) of the catalysts was also very apparent during this run. Figure 7 shows that similar results were observed for PX2. A very distinct peak of $0.76 \mathrm{~mol} / \mathrm{min}$ was observed, along with a rapid decrease to below $0.15 \mathrm{~mol} / \mathrm{min}$. These results were consistent with results reported in the literature, ${ }^{9}$ i.e., for shorter induction periods, higher maximum $\mathrm{H}_{2}$ generation rates and faster deactivations can occur. However, it has recently been shown that this may not always be the case. 12 
A comparison of the graphs shows that the 25 \% excess formic acid resuled in a $53 x$ increase in the maximum $\mathrm{H}_{2}$ gencration rate (based on the lower value of $0.4 \mathrm{~mol} / \mathrm{min}$ ). It also shortened the induction perlod by 2 to 3 hr. Overall, these results clearly exemplified the importance of determining the correct formic acid requirement for each sludge, based on the method developed by Hsu. 12

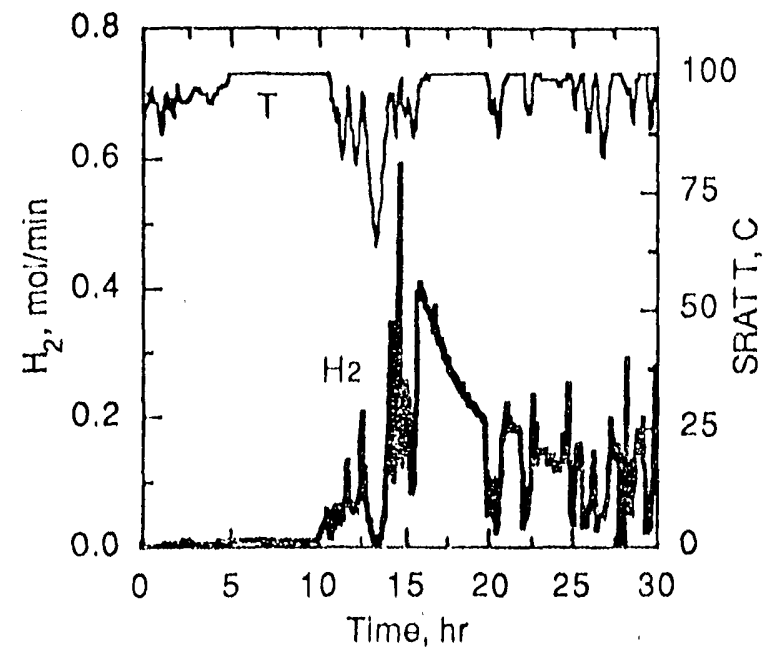

Figure $6 . \mathrm{H}_{2}$ generation rate for $\mathrm{PX} 1$ through PHA addition.

It is noteworthy that these results also compared well with laboratory scale experiments performed with both simulated 12 and actual HLW sludges. As a result, they were used to redesign the DWPF feed preparation system. A forced air purge system and $\mathrm{H}_{2}$ monitors were recommended to control the generation of $\mathrm{H}_{2}$ during feed preparation by fuel dilution.

\section{BL, HM and PX: Activation Energies}

The $\mathrm{H}_{2}$ generation rate during heating and cooling of the SRAT was used to determine an apparent activation energy. An average value of $110 \mathrm{~kJ} / \mathrm{mol}$ was detcrmined from all of the runs. Furthermore, laboratory studies showed that the most active catalyst in the HLW thas Rh, followid by $\mathrm{Ru}$ and then $\mathrm{Pd}$, which was relatively much less active.12 These results suggested that the apparent activation energy was probably related to the activity of ciltier $\mathrm{Rh}$ or Ru.

Bond 7 listed numerous activation energles for the decomposition of formic acid by various inctals in different bulk forms, i.e., supported, film, powder, etc., and at different conditions. The values ranged form 27 to $209 \mathrm{~kJ} / \mathrm{mol}$, where these extreme values corresponded $10 \mathrm{Pt}$ foil and $\mathrm{Fe}$ powder, respectively. A value of $105 \mathrm{~kJ} / \mathrm{mol}$ was, however, reported for $R h$, which whs nearly the same as lhat obtained in this work.

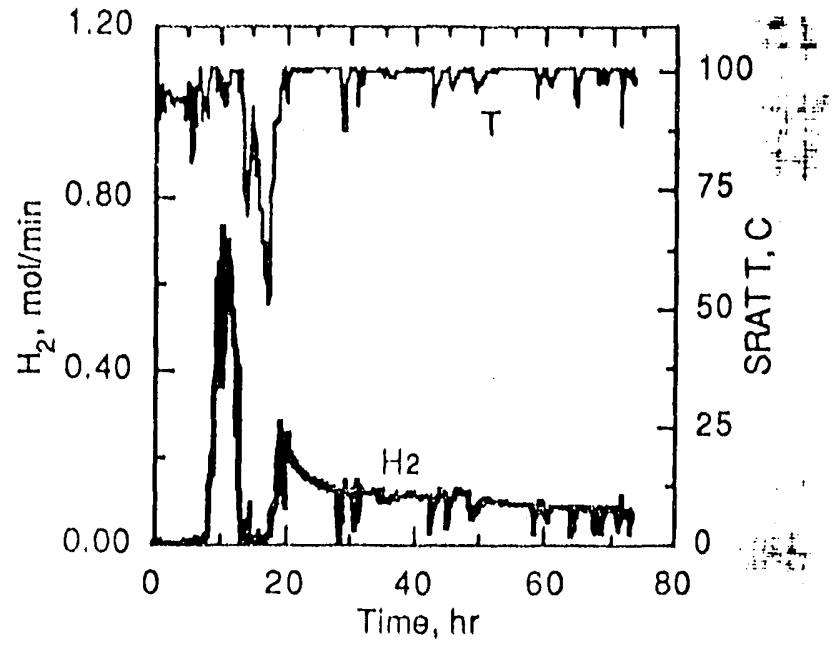

Nigure $7 . \mathrm{H}_{2}$ generation rate for $\mathrm{PX2}$ llirough the end of the feed preparation cycle.

It should be noted that much of the literature data were obtained at iemperatures ranging form 120 to $160{ }^{\circ} \mathrm{C}$, compared to 80 to $100^{\circ} \mathrm{C}$ in this study. Furthermore, the data reported by Bond ${ }^{7}$ were obtained using formic acid vapor. Nevertheless, similar results have been reported using aqueous formic acid. ${ }^{10}$

\section{CONCLUSIONS}

The levels of $\mathrm{H}_{2}$ observed in this study were such that the L.FL of $\mathrm{H}_{2}$ in air (4 volx) could be exceeded in DWPF vessels, which do not presently have air purges. Therefore, the installation of a forced air purge system and $\mathrm{H}_{2}$ monitors were recommended 10 the DWPF 10 control the generation of $\mathrm{H}_{2}$ in the feed preparation system by fuel dilution.

The results of the parametric study showed the following: All the IDMS runs exhibited an induction period, followed by a rapid increase in the $H_{2}$ generation rate 10 a fairly sharp maximum and then a continuous decrease 10 levels far below the maximum. A laboratory study showed that the most active metals were $R h$ and $R u$, and that their reduction by formic acid to an active metallic state was the cause of the induction period. The induction period also decreased with lower concentrations of nitrite and with higher concentrations of formic acid. Higher maximum $\mathrm{H}_{2}$ generation rates also resulted for lower nitrite and higher formic acid concentrations. However, the $\mathrm{H}_{2}$ generation rate was insensitive to higher concentrations of formate. 
There was Hlso considerable evidence, based on comparing the results of this study with those reported in the literature, which supported the supposition that the $\mathrm{H}_{2}$ was produced via heterogeneous catalysis. The formio acid first reduced the noble metals to a calalytically active metallic state. Then the active metals adsorbed and decomposed the formic acid into $\mathrm{H}_{2}$ and $\mathrm{CO}_{2}$, according to Equation 1. It should be emphasized that the inherent obscurity of heterogeneous catalytic reactions, (i.e., the reaction rate generally depends on unknown parameters, e.g., the particle size, surface area, etc.), combined with the inhomogeneity of simulated (and of course actual) HLW sludge, understandably made the results of this study, in some cases, difficult to interpret.

\section{ACKNOWLEDGEMENT}

The information contained in this article was developed during the course of work under Contract No. DE-AC09-89SR 18035 with the U. S. Department of Energy.

\section{REFERENCES}

1. N. D. Hutson, J, R, Zatnecnik, J. A, Ritter and J. T. Carter, "Pilot Scale Processing of Simulated Savannah River Site High Level Radioactive Waste," Boceedings of the 1921 Joint International Waste Management Conference, 215 (1991).

2. S. R. Young, H. B. Shah and J. T. Carter, "Separation of Aromatic Precipitates from Simulated High-Level Radioactive Waste by Hydrolysis, Evaporation and Liquid-Liquid Extraction," Daper Ne. 81d, AIChE Summer National Meeting, Pittsburgh, PA (1991).

3. J. A. Rilter, N. D. Hutson, J, R, Zamecnik and J. T. Carter, "Immobilization of Simulated HighLevel Radioactive Waste in Borosilicate Glass: Pilot Scale Demonstrations," in Nuclear and Hazardous Waste Management. Vol IV, (G. Wicks, D.Bickford and R. Bunnel, eds.), Amer. Nuclear Soc., New York (1991).

4. J. R. Zamecnik, N, D. Ilutson, J, A. Ritter and J. T. Carter, "The Processing of Simulated Hilgh Level Radoactive Waste Sludges Comaining Nirrites and Mercury," High Leyel Ridlloactive Waste Managementi Proccesings of the Second Annual InLemational Conference, 1 . 427 (1991).

5. K. D. Wiemers, "Gas Release During Formating of a Simulated Hanford Waste Vitrification Plant Feed, ${ }^{*}$ BNL-SA-15265, Pacific Northwest Laboralory (1988).

6. C. W. Hsu, "Hydrogen Evolution During Formic Acid Treament of Sludge Simulant," WVSBC-RP-
20-6.64. Sayannah River Laboratory (1990).

7. G. C. Bond, Calalysis by Metals Academic Press, Inc., London (1962).

8. C. N. Satterfield, Hebregeneous Calalysis in Bracilce McGraw-Hill, Inc., New York (1980),

9. E. Müller and W. Lurpabel, "Ihe Catalytic Decomposition of Aqueous Solutions of Formic Acid by the Platium Metals IV [German]," Monatshefte für Chemie 53, 825 (1929).

10. D. M. Ruthen and R. S. Upadhye, "The Catalytic Decomposition of Aqueous Formic Acid over Suspended Palladium Catalysts," L Catalysis, 21,39 (1971).

11. S. P. Hill and J. M. Winterboltom, "The Conversion of Polysaccharides to Hydrogen Gas. Part 1: The Palladium Catalyzed Decomposition of Formic Acld/Sodium Formate Solutions," L.Chem. Tech. Biotechnel., 41, 121 (1988).

12. C. W. Hsu and J. A. Ritter, "On the Generation of Hydrogen from Formic Acid-Treated Simulated High-Level Radioactive Waste," to be presented at the AlChE Summer National Meeting, Minneapolis, MN (1992).

13. C. W. Hsu, "Formic Acid Requirement in the DWPF Chemical Processing Cell," WSRC-RP. 20-554. Savannah River Laboratory (1990). 

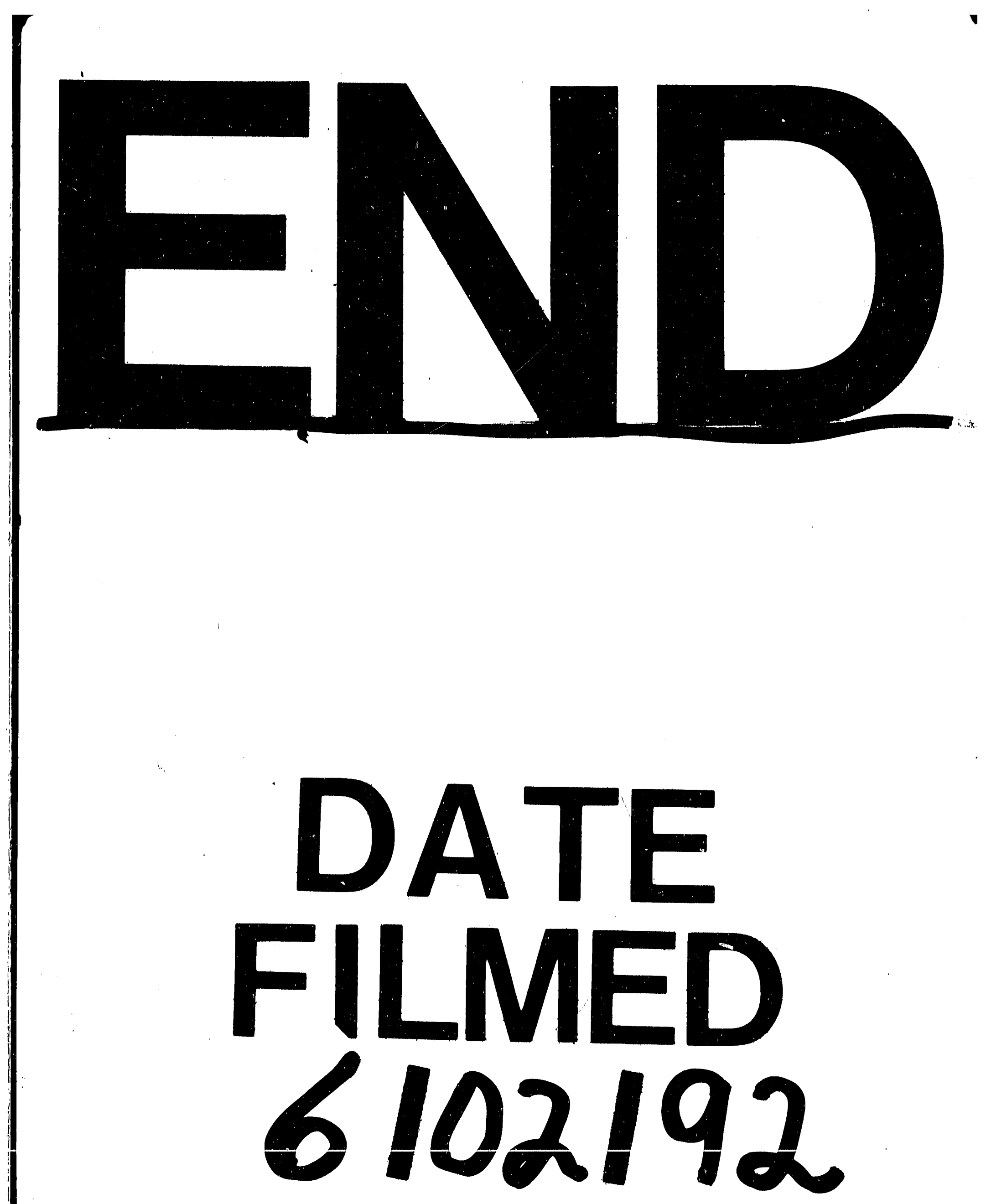
